THE JOURNAL GASTRONOMY TOURISM

Volume 2 Nomor 1, Juni 2015, 1-7

Tersedia daring di:

https://ejournal.upi.edu/index.php/gastur

\title{
PENGARUH KOMPETENSI ACHIEVEMENT AND ACTION DAN KOMPETENSI HELPING AND HUMAN SERVICE TERHADAP KINERJA KARYAWAN F\&B DEPARTEMENT DI HOTEL MUTIARA BANDUNG
}

Ayu Rima, Dewi Turgarini dan Sylvia Meilani

Program Studi Manajemen Industri Katering Fakultas Pendidikan Ilmu Pengetahuan Sosial Universitas Pendidikan Indonesia Bandung 40154

e-mail: ayu.rima01@gmail.com

\begin{abstract}
The purpose of this research is to measure the influence of Achievement and Action Competence Variabel $\left(X_{1}\right)$ as well as Helping and Human Service Competence Variabel $\left(\mathrm{X}_{2}\right)$ on Performance $(Y)$. Based on survey results revealed that the level of Achivement and Action Competentence to performance is equal to 79\%, while the level of Helping and Human service Competenceis 19\%. Simultaneously, Achivement and Action Compentence as well as helping and Human Service affect the performance on $F \& B$ Departement employee significantly.

Keywords : Achievement and action Competence, helping and Human service Compentence, and performance.
\end{abstract}

\begin{abstract}
Abstrak
Tujuan penelitian ini adalah untuk melihat seberapa besar pengaruh variabel Kompetensi Achievement and Action $\left(\mathrm{X}_{1}\right)$ dan variabel Kompetensi Helping and Human Service $\left(\mathrm{X}_{2}\right)$ terhadap Kinerja Karyawan (Y). Hasil penelitian di lapangan menunjukan bahwa tingkat Kompetensi Achievement and Action terhadap kinerja yaitu sebesar 79,7\%, sedangkan kompetensi Helping and Human Service terhadap kinerja sebesar 9\%. Secara simultan, kompetensi achievement and action dan kompetensi helping and human service memberikan pengaruh terhadap kinerja F\&B Departement Hotel Mutiara Bandung.

Kata kunci : Kompetensi achievement and action, Kompetensi helping and human service, dan Kinerja Karyawan
\end{abstract}

\section{PENDAHULUAN}

Terdapat berbagai klasifikasi Hotel di bandung dari Hotel Bintang 5, 4, 3, 2, 1 bahkan kelas melati. Hotel dengan kelas bintang tiga selalu menjadi alternatif para wisatawan nusantara maupun mancanegara memliki tempat yang nyaman serta harga yang terjangkau, di bawah ini adalah daftar hotel bintang tiga di bandung.

Hotel Mutiara sebagai salah satu hotel dengan kelas bintang tiga di Bandung yang menjadi tempat tujuan menginap yang memiliki 118 kamar. Departement Food and Bevarage $(\mathrm{F} \& \mathrm{~B})$ merupakan bagian yang mempunyai peranan penting didalam hotel yang dituntut untuk selalu menciptakan inovasi dalam produk serta memberikan pelayanan yang maksimal untuk konsumen, tingkat persaingan pasar yang semakin ketat menuntut setiap perusahaan termasuk Hotel Mutiara harus mampu melakukan 
perubahan strategi untuk perbaikan dalam perusahaan, perbaikan strategi ini bisa berupa penyempurnaan sistem manajemen, strategi pemasaran dan penjualan, ataupun peningkatan pembinaan kualitas sumber daya manusia yang dimiliki, hal ini harus dilakukan secara konsisten oleh perusahaan sehingga perusahaan dapat mengantisipasi kondisi pasar yang semakin dinamis.

Sebagai perusahaan yang bergerak dalam bidang jasa, peran sumber daya manusia merupakan aset operasional perusahaan. Kinerja karyawan merupakan salah satu hal terpenting bagi perusahaan, kinerja seringkali dijadikan indikator bagi berhasil tidaknya perusahaan memberikan layanan kepada konsumen, bagi perusahaan kinerja adalah seberapa baik karyawan memberikan kontribusinya bagi perusahaan.

\section{Tabel 1.3}

Kriteria Penilaian Kinerja Karyawan

\begin{tabular}{|c|c|c|c|c|c|}
\hline Penilaian Kinerja & $\begin{array}{c}\text { San } \\
\text { gat } \\
\text { Baik } \\
(\%)\end{array}$ & $\begin{array}{l}\text { Bai } \\
\mathbf{k} \\
(\% \\
)\end{array}$ & $\begin{array}{c}\text { Cuk } \\
\text { up } \\
(\%)\end{array}$ & $\begin{array}{c}\begin{array}{c}\text { Kura } \\
\text { ng }\end{array} \\
(\%)\end{array}$ & $\begin{array}{c}\text { Sangat } \\
\text { Kuran } \\
\mathbf{g} \\
(\%)\end{array}$ \\
\hline Penampilan & 30 & 25 & 20 & 25 & 0.00 \\
\hline komunikasi & 20 & 35 & 35 & 10 & 0.00 \\
\hline Waktu Kehadiran & 25 & 10 & 60 & 5 & 0.00 \\
\hline Disiplin Kerja & 10 & 35 & 45 & 10 & 0.00 \\
\hline Kemampuan Bekerja & 20 & 45 & 30 & 5 & 0.00 \\
\hline $\begin{array}{l}\text { Kemampuan melaksanakan } \\
\text { instruksi }\end{array}$ & 30 & 20 & 45 & 5 & 0.00 \\
\hline Tanggung jawab & 10 & 35 & 30 & 5 & 0.00 \\
\hline Jumlah & $\begin{array}{c}20.7 \\
1\end{array}$ & $\begin{array}{l}29 . \\
28\end{array}$ & $\begin{array}{c}37.8 \\
5\end{array}$ & 10 & $\mathbf{0}$ \\
\hline
\end{tabular}

Sumber : HRD Hotel Mutiara Bandung, Maret 201

Dari hasil wawancara pada prapenelitian dengan pihak manajemen pada tanggal 20 maret 2012 didapatkan bahwa penilaian kinerja karyawan di Hotel Mutiara dilakukan satu kali dalam satu tahun data pada tabel diatas menggambarkan penilaian karyawan yang masih relatif rendah.. Permasalahan disiplin kerja karyawan, absensi ataupun adanya perselisihan antar karyawan sehingga menyebabkan terhambatnya beberapa pekerjaan dikarenakan terganggunya proses kerjasama di antara karyawan.

Hotel Mutiara sebagai hotel bintang tiga yang mempunyai daya saing tinggi tidak hanya memerlukan karyawan yang berkemampuan rata-rata saja tetapi perlu mengevaluasi penilaian kinerjanya agar semua karyawan dapat memiliki kompetensi yang baik untuk memenangkan pasar, dua faktor yang mempengaruhi kinerja yakni kompetensi achievement and action dan kompetensi helping and human service. 
Seperti yang telah dikemukakan Payaman J. simanjuntak (2005: 10), kinerja dipengaruhi oleh tiga faktor yaitu kompetensi individu yang bersangkutan, dukungan organisasi dan dukungan manajemen.

Berdasarkan latar belakang masalah tersebut di atas, maka penulis tertarik untuk mengadakan penelitian yang hasilnya dituangkan dalam bentuk skripsi dengan mengambil judul : "Pengaruh Kompetensi Achievement and Action dan Kompetensi Helping and Human Service Terhadap Kinerja Karyawan F\&b Departement di Hotel Mutiara Bandung".

\section{METODE PENELITIAN}

Jenis penelitian ini adalah survei sedangkan metodenya yaitu deskriptif analitis . Metode Survei Deskriptif adalah suatu metode penelitian yang mengambil sampel atau populasi dan menggunakan kuesioner sebagai alat pengumpulan data. Dalam penelitian ini data dan infomasi dikumpulkan dari responden dengan menggunakan kuesioner. Setelah data diperoleh kemudian hasilnya akan dipaparkan secara deskriptif dan pada akhir penelitian akan dianalisis untuk menguji hipotesis yang diajukan pada awal penelitian ini. Effendi dalam Riduwan (2004 : 276).

Metode yang digunakan dalam pengumpulan data pada penelitian ini adalah observasi, wawancara, kuesioner, dan studi literatur.

\section{Operasional Variabel}

\section{A. Kompetensi Achievement and action}

Kompetensi Achievement and Action (Merencanakan dan mengimplementasikan) adalah semangat untuk berprestasi atau untuk mencapai target kerja, derajat kepedulian seseorang terhadap pekerjaannya sehingga ia terdorong berusaha untuk bekerja dengan lebih baik atau diatas standar.

Kompetensi Achievement and action yang dimaksud dalam penelitian ini mengacu pada pendapat Spencer \& Spencer. Variabel ini diukur dengan menggunakan skala ordinal yang mencangkup indikator-indikator yaitu $\mathrm{ACH} /$ Achievement Orientation ( semangat untuk berprestasi atau untuk mencapai target kerja), CO/ Concern For Order ( perhatian terhadap kejelasan tugas kualitas dan ketelitian kerja).

\section{B. Kompetensi Helping and Human Service}

Spencer dan Spencer ( 1993:10) kompetensi helping and human service/melayani, merupakan cluser yang terdiri dari pemahaman secara Empati (interpersonal dan orientasi terhadap pelayanan pelanggan) yaitu kemampuan untuk memahami hal-hal yang tidak diungkapkan dengan perkataan yang bisa berupa atas pemahaman perasaan, keinginan atau pemikiran dari orang lain, mencangkup mendengarkan, respon dengan orang lain, sadar perasaan orang lain, cara pemahaman.

Variabel ini diukur dengan menggunakan skala ordinal yang mencangkup indikator-indikator yaitu IU/ Interpersonal Understanding ( empati), CSO/ Customer Service Orientation ( berorientasi kepada pelanggan). 


\section{Kinerja}

Kinerja adalah Hasil kerja secara kualitas dan kuantitas yang dicapai oleh seorang pegawai dalam melaksanakan tugasnya sesuai dengan tanggung jawab yang diberikan kepadanya A.A.Prabu Mangkunegara, (2008:67).

Menurut Gomez (dalam Utomo, 2006) dalam melakukan penelitian terhadap kinerja yang berdasarkan perilaku yang spesifik (Judgement Performance Evaluation) ini maka ada delapan dimensi yang perlu mendapatkan perhatian, antara lain:

1. Quality of Work (kualitas kerja)

Kualitas ini akan dicapai berdasarkan syarat-syarat kesesuaian dan kesiapan.

2. Quantity of Work (kuantitas kerja)

Jumlah kerja yang dilakukan dalam suatu periode waktu yang ditentukan.

3. Job Knowledge (pengetahuan pekerjaan)

Luasnya pengetahuan mengenai pekerjaan dan ketrampilan.

4. Creativeness (kreatifitas)

Keaslian gagasan-gagasan yang dimunculkan dan tindakan-tindakan untuk menyelesaikan persoalan-persoalan yang timbul.

5. Cooperative (kerjasama)

Kesadaran untuk bekerja sama dengan orang lain.

6. Initiative (inisiatif)

Keaslian ide-ide yang disampaikan sebagai program organisasi dimasa yang mendatang.

7. Dependerability (ketergantungan)

Kesadaran dapat dipercaya dalam hal kehadiran dan penjelasan kerja.

8. Personal Quality (kualitas personil).

\section{Teknik Analisis Data}

Pada penelitian ini terdapat dua variabel independent yaitu kompetensi achievement and action, kompetensi helping and human service, serta variabel dependent yaitu kinerja. Metode yang digunakan adalah metode deskriptif verifikatif yang diolah menggunakan program SPSS 19 melalui kuesioner sebagai alat pengumpul data. Teknik yang akan digunakan dalam penelitian ini adalah sampling jenuh. Sampling Jenuh adalah teknik penentuan sampel bila semua anggota populasi digunakan sebagai sampel menurut sugiyono (2011:68). Hal ini sering digunakan bila jumlah populasi relatif kecil, kurang dari 30 orang atau penelitian yang ingin membuat generalisasi dengan kesalahan yang sangat kecil. Istilahnya adalah sensus, dimana semua anggota populasi dijadikan sampel.

Penelitian ini menggunakan sampling jenuh karena dalam penelitian ini populasinya relative kecil yaitu 32 karyawan F\&B Departement.

\section{HASIL PEMBAHASAN}

Hotel Mutiara Bandung berbadan hukum dengan nama PT.Sumber Agung bergerak dibidang jasa perhotelan dan restoran, Mutiara Hotel Bandung berlokasi di Jl Kebon Kawung No.60. Bandung 40171 Jawa Barat- Indonesia dengan telepon : 
(022) 4200333 / (022) 420888 fax : (022) 420111 email : info@mutiarahotel.com website : www.mutiarahotel.com berdiri sejak tahun 1972.

Awal mula hotel ini berdiri hanya mendirikan 75 kamar dan fasilitas yang terbatas. Sejalan dengan perkembangan zaman dimana sektor pariwisata meningkat dengan sangat pesat, maka pada tahun 1993 Hotel Mutiara mulai berkembang dan direnovasi/ ditingkatkan menjadi hotel yang representative. Representative baik itu bangunan, management, sumberdaya manusia, pelayanan serta sarana penunjang/ fasilitas lainnya hingga mencapai 118 kamar.

Dari hasil penelitian yang diperoleh, maka dapat dilakukan pembahasan mengenai pengaruh-pengaruh antara kompetensi achievement and action (X1) dan Kompetensi helping and human service (X2) terhadap kinerja F\&B department Hotel Mutiara Bandung.

Berdasarkan pengumpulan data dari 32 responden F\&B department Hotel Mutiara bandung, diketahui bahwa karakteristik responden dengan presentase tertinggi berdasarkan jenis kelamin yaitu laki-laki sebanyak 30 orang atau sebesar 93.75\% dibandingkan perempuan yang hanya berjumlah 2 orang saja, karena selain dari pihak manajemennya yang menginginkan laki-laki hal lain juga bahwa dalam area kitchen terdapat barang-barang yang relatif besar dan membutuhkan tenaga yang ekstra, selain itu dalam hal memasak juga selalu membuat dalam jumlah yang banyak maka dikhawatirkan. Hal tersebut dilakukan pihak manajemen untuk mengurangi resiko kecelakaan pada perempuan.

Berdasarkan usia kebanyakan yang bekerja di Hotel Mutiara anatara 31 sampai 40 tahun sebesar $46.88 \%$ karena pada usia tersebut masa produktifitas kerjanya masih kuat dan terbilang cukup sedangkan, Berdasarkan pendidikan terakhir mayoritas yang berpendidikan pada tarap SMA/SMK/STM sebesar $71.88 \%$ khususnya SMK yang memiliki keterampilan dan pengetahuan dibidangnya sehingga memudahkan jika mereka langsung turun kelapangan dan sudah mengerti karena setidaknya tidak jauh dengan ilmu yang mereka dapat di bangku SMK dan terakhir karakteristik responden berdasarkan masa kerja, di Hotel Mutiara Bandung responden mayoritas bekerja sudah 1 sampai 5 tahun sebesar $40.62 \%$.

Hasil uji hipotesis menunjukan bahwa kompetensi achievement and action berpengaruh positif dan signifikan terhadap kinerja sebesar 3.183 dan hasil uji hipotesis menunjukan bahwa Kompetensi helping and human service berpengaruh positif dan signifikan terhadap kinerja sebesar 1.714. Besarnya pengaruh kompetensi achievement and action dan kompetensi helping and human service secara bersamasama terhadap kinerja yaitu 0.377 atau $37,7 \%$ dan sisanya $62,3 \%$ dipengaruhi faktor lain seperti motivasi, kompensasi, lingkungan kerja dan lainnya

Berdasarkan hasil uji hipotesis yang dilakukan, diperoleh hasil bahwa kompetensi achievement and action dan kompetensi helping and human service berpengaruh terhadap kinerja, hal ini sesuai dengan pendapat Payaman J. simanjuntak (2005: 10), kinerja dipengaruhi oleh tiga faktor yaitu kompetensi individu yang bersangkutan, dukungan organisasi dan dukungan manajemen. 


\section{KESIMPULAN}

Berdasarkan penelitian yang telah dilakukan pada karyawan mengenai pengaruh kompetensi achievement and action dan kompetensi helping and human service terhadap kinerja karyawan F\&B department Hotel Mutiara Bandung, maka dapat ditarik kesimpulan sebagai berikut :

1. Kompetensi Achievement and Action berpengaruh terhadap kinerja karyawan, jika kompetensi Achievement and Action sesuai dengan yang diharapkan oleh perusahaan akan berpengaruh terhadap kinerja karyawan .Artinya bila kompetensi Achievement and Action memiliki respon yang baik maka kinerja karyawan F\&B department Hotel Mutiara Bandung akan semakin meningkat.

2. Kompetensi Helping and Human Service berpengaruh terhadap kinerja karyawan. Jika Kompetensi Helping and Human Service diterapkan pada standar kerja perusahaan maka akan berpengaruh terhadap kinerja karyawan $\mathrm{F} \& \mathrm{~B}$ department Hotel Mutiara Bandung. Artinya dengan menerapkan kompetensi helping and human service dengan baik dan sesuai dengan standar kerja perusahaan maka kinerja karyawan F\&B department Hotel Mutiara Bandung akan semakin meningkat.

3. Kompetensi Achievement and Action dan Kompetensi Helping and Human service berpengaruh terhadap kinerja karyawan F\&B department Hotel Mutiara Bandung. Artinya Apabila Kompetensi Achievement and Action dan Kompetensi Helping and Human Service diterapkan dengan baik berdasarkan standar kerja perusahaan maka kinerja karyawan F\&B department Hotel Mutiara Bandung akan meningkat.

\section{DAFTAR PUSTAKA}

Arikunto, Suharsimi. 2006. Prosedur Penelitian Suatu Pendekatan Praktek. Edisi Revisi VI. Jakarta : PT. Rineka Cipta

Boulter, Nick, Dalziel, Murray \& Hill Jackie, 2003, People and competencies : The Route to ompetitive Advantage, Alih Bahasa : Bern Hidayat, Jakarta : PT. Gramedia Pusaka Utama.

Dessler, Garry, 2005, Manajemen Sumber Daya Manusia Jilid 2, Jakarta : PT Prehallindo.

IIlyas, Y., 2002, Kinerja, Teori, Penilaian dan Penelitian etakan III, Depok : Pusat Kajian Ekonomi Kesehatan FKM-UI

Mangunegara P Anwar. 2000.Manajemen Sumber Daya Manusia Perusahaan. Bandung: PT Remaja Rosdakarya bandung.

Prof. Dr Wibowo, S.E., M.Phil.2007. Manajemen Kinerja. Jakarta : PT Rajagrafindo Persada.

Riduan, 2004. Dasar-dasar statistika.

Simanjuntak, payaman J., 2005, Iptek dan Pengembangan Sumber Daya Manusia, Jakarta. Universitas Krisnadwipayana

Soeprihanto, john., Harsiwi, Hadi prakoso, 2003, perilaku Organisasi, Yogyakarta : Penerbit STIE 
Spencer, Lyle M \& Spencer, Signe M, 1993, Competence at Work : Models for Superior Performance, New York : John Wiley \& Sonc, Inc

Sugiyono.2011. Statistika untuk penelitian. Jakarta:Alfabeta.

Sugiyono.2010. Statistika untuk penelitian. Jakarta:Alfabeta.

Sugiyono 2000. Metode Penelitian Administrasi.Bandung:Alfabeta.

Sulastiyono, Agus, M. Si, 2006, Manajemen Penyelenggara Hotel edisi 1, Bandung : Alfabeta.

Tarmudi,mas.2010.Pengertian observasi (online) tersedia :http://mastarmudi.

blogspot.com/2010/07/pengertian-observasi.html. Akses juli 2012

Triffin \& McCormick, 1979, Industrial Psychology, New Delhi : Prentice- Hall.

Widayanti Denti, S.Si., Apt. 2010. Tesis Pengaruh Kompetensi manajerial dan Motivasi terhadap Kinerja Pengelola Obat Puskesmas Dinas Kesehatan Kabupaten Subang. Bandung : Universitas Pendidikan Indonesia

Veithzal. Rivai, 2004. Manajemen Sumber Daya Manusia untuk Perusahaan. Jakarta : PT Raja Grafindo Persada. 